山्山FFRANÇAISE

$\supset \mathrm{DE}$

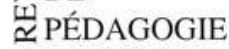

\section{Revue française de pédagogie}

Recherches en éducation

$186 \mid 2014$

Les trajectoires des inspections scolaires en Europe : analyses comparatives

\title{
Inspectorates and Politics: the trajectories of school inspection in England and Scotland
}

Inspections et politique : les trajectoires des inspections scolaires en Angleterre et en Écosse

Jenny Ozga et Martin Lawn

\section{(Q) OpenEdition}

\section{Journals}

Édition électronique

URL : http://journals.openedition.org/rfp/4388

DOI : $10.4000 /$ rfp.4388

ISSN : 2105-2913

Éditeur

ENS Éditions

Édition imprimée

Date de publication : 1 janvier 2014

Pagination : 11-21

ISBN : 978-2-84788-639-9

ISSN : 0556-7807

Référence électronique

Jenny Ozga et Martin Lawn, «Inspectorates and Politics: the trajectories of school inspection in England and Scotland », Revue française de pédagogie [En ligne], 186 | 2014, mis en ligne le 01 janvier 2017, consulté le 20 avril 2019. URL : http://journals.openedition.org/rfp/4388 ; DOI : 10.4000/ rfp.4388 


\section{Inspectorates and Politics: the trajectories of school inspection in England and Scotland}

\section{Jenny Ozga and Martin Lawn}

Cet article étudie l'influence des changements de la gouvernance de l'éducation en Europe sur les trajectoires des inspections et se concentre pour cela sur le système d'inspection de l'Ofsted en Angleterre et sur celui de l'inspection de Sa Majesté en Écosse (HMIE). Pour établir cette comparaison, nous analysons d'abord les caractéristiques historiques propres à chaque inspection avant d'envisager les principaux changements du travail et du positionnement de chacune d'elles et de discuter dans quelle mesure ces trajectoires sont déterminées par les changements politiques nationaux. Nous mettons ainsi en évidence un contraste entre le nouveau cadre d'inspection de l'Ofsted, qui cible les écoles aux performances insuffisantes dans un contexte d'accroissement du contrôle du pouvoir central en vue d'améliorer les résultats, et la promotion par l'inspection écossaise de l'autoévaluation et de l'apprentissage collaboratif dans un contexte où le Parti national écossais (SNP) au gouvernement continue de vouloir affirmer l'indépendance écossaise.

Mots-clés (TESE) : inspection, gouvernance, évaluation, politique en matière d'éducation, Angleterre, Écosse.

\section{INTRODUCTION}

This paper reports on some of the findings from recent research ${ }^{1}$, where we focus on a group of policy actors the inspectorate-who occupy a significant position in new governing processes and practices, mediating between external and local governing pressures, databased evidence and institutional cultures and practices (Ozga et al. 2011). In both national systems under discussion here, inspectorates have occupied positions of historical importance, propagating a narrative of their independence (from government) and their expert, auton- omous, professional judgement. In the new context of networked governance, supported by data, do inspectorates maintain their authority? Does the European arena offer opportunities for national inspectorates to strengthen their authority? In the development of current inspection regimes, is there a trade-off between (political) independence and power? Our analysis suggests that the two inspectorates retain a significant role in the governing of education, but that their roles have been seriously disrupted and continue to be subject to change. Their capacity to secure their position is heavily influenced by the politics in play in their respective contexts: these 
present very different opportunities for the enactment of inspection, as we attempt to show below.

Our research is framed by the increase in inspection activity throughout Europe, and by evidence of increasing and coordinated efforts to internationalise inspection outcomes in Europe (Tersmette 2001; Grek et al. 2013). In this context inspectors confront, translate and make "actionable" the mass of information carried by data within and across Europe (Grek \& Lawn 2010). They do this in situations where the trajectory of their development may be strongly influenced by the benchmarking and competitive performance regimes of transnational organisations, including the EU and the OECD. This influence re-positions inspectorates in quite complex and contradictory ways. On the one hand there is the persistence of performance monitoring at European and (to varying degrees) at national levels through target-setting, indicators and benchmarks, and on the other the promotion of self-evaluation and "light touch" inspections that express a "softer" governance turn, and a concern to promote self-regulation or self-evaluation as the best basis for constant improvement (Lawn 2006). Our cases may be read as distinct strategic choices, in which the trajectory of development is shaped by the particular politics in play in the two contexts.

Before moving to consideration of the two cases, we say something briefly about our methodology. We conceptualise inspection as a site for investigation of the interaction of historically-embedded assumptions and practices on the mediation of global policy trends including trends in governance (Clarke 2009; Ozga et al. 2011). This requires us to be attentive to history and cultural formations in different national contexts, while understanding that they are trans-nationally connected. We therefore undertake extensive analysis of policy texts and interviews with key system actors at a number of "levels" of enquirytransnational, national, local and school-based. The first phase of the research explored the relationship between trends in inspection, the work of $\mathrm{SICl}$, and the level of national and transnational engagement of the inspectorates in our study. The second phase examined nationallocal relations as revealed through inspection arrangements, while the third took the research to the context of the individual school. Throughout the enquiry we draw on critical discourse analysis (Fairclough 2001) to seek to make visible the relations between text, discursive practices and wider policy, especially where these connect to power relations between policy actors located in different policy spaces. The work of analysis therefore includes interrogation of official literature and of inspection hand- books and frameworks, along with a large sample of inspection reports (50 in each system); interviews with key "system actors" including inspectors, officials, head teachers and teachers at the inter-national, national and local levels (90 in total); it also includes investigation of the background, training, experience and "assumptive worlds" of each national inspectorate. There are also detailed case studies of a sample of inspection "events" (four in each system) as they unfold, and in relation to their effects on the participants. The case studies make use of analysis of relevant documentation, and interviews with key actors. In this paper, we discuss only a selection of our data that relates to the review offered here of major changes in the inspectorates in England and Scotland. For further discussion of the project findings see Grek, Lawn, Ozga and Segerholm (2013), Ozga and Lawn (2014) and Grek and Lindgren (2014) or visit the project website: <http://www. education.ox.ac.uk/governing-by-inspection/>

We first consider briefly the history of the Scottish and English Inspectorates of education, before focusing on the influence of the changing political context on their current positioning in the two countries/systems.

\section{THE HISTORY AND DEVELOPMENT OF THE INSPECTORATES IN ENGLAND AND SCOTLAND}

The histories presented here are not exhaustive, but focus on critical moments and key shifts in the development of the two inspection regimes. This history remains a reference point for many current inspectors-even where there are breaks and disjuncture in the narrative of development (Grek 2013). In both systems we can track inspection to its nineteenth century origins, and link its emergence to the growing provision of mass education, and the need of government to ensure minimum standards and effectiveness in spending public funds. Inspectors have been significant figures for policy makers and teachers, schools and local authorities for a long time; they occupy a central - if shifting - place in the landscape of schooling. Here we ask: does the history of inspectorates help us to understand why they remain in place in the 21 st century, and in a very different context of governing education?

\section{The history of inspection in England}

Some key dimensions of the history of the inspectorate in England stand out. The claim to the independence of the inspectorate is central: the distinctive status of 
His/Her Majesty's Inspectorate-appointed by Her Majesty the Queen through an order of the Privy Councilcreated a formal distance from the Board/Ministry/ Department of Education as it moved through its various iterations, and that independent status is still explicitly referenced in descriptions of Ofsted by Ofsted (The Office for Standards in Education, the organisation in which inspection is now lodged in England). This independence was illustrated in the control exercised by HMI over their reporting processes: their reports on the state of education were made to schools and to the Ministry/ Department, which had to publish them without intervention. As Kogan put it "No administrator would dare challenge an HMl's report" (Kogan 1971).

In 1839, Parliament decided that no further grants for education should be made without the right of inspection in order to ensure the proper use of public funds, and in the same year the two first inspectors of education were appointed. Writing in 1960, a former Inspector noted that:

We are still appointed in the same way and have retained the title "Her (His) Majesty's Inspector". The form of appointment derives from Tudor times, and over a century it has helped to safeguard and still symbolises our cherished independence of judgment (Allen 1960, 235).

In the late nineteenth century in England, schooling was heavily stratified into a restricted elite secondary education and mass elementary provision, the official purpose of which was limited to equipping the workforce with basic skills, and the tools of governance included central grants, examinations, handbooks of suggestions for teachers and inspections. Oversight of the system, particularly in terms of its efficiency, depended upon HMI judgement. With the exception of financial information on levels of expenditure, the system was without data. As a result, "HM Inspectorate relied on a strong collegiate tradition and shared experience (as well as internal guidelines) to achieve reliability and common practice" (Maclure 1988, 21-2) and probably focused on value for money. In a paper written for a European audience, an $\mathrm{HM}$ Inspector described the work of the inspectorate in England in the post-war years before changes in the 1970s. The emphasis was on presenting the inspectorate as not a regulatory agency, nor as "political" but as acting within the limits of government policy. It offered advice but this could be ignored. It had a limited number of formal areas to report on and yet might offer, at school and national level, a much wider set of impressions:
These reports express the opinion of the inspector, who is expected to give his own views without fear or favour; in assessing school work he speaks for himself and not as a mouthpiece of the government. When, of course, he is acting as the Minister's emissary or representative, he must be careful to speak within the range of government policy (Allen 1960, 236).

Other contemporary sources underline the respect accorded to HMI on the basis of their "prestige, high reputation and expertise" that was also connected to their style of reporting that encouraged the best schools and "gently rebuke(d)" the worst (Kogan 1970, 20). Inspectors thus exercised a form of discursive power, managed through conversations and reports, which reflected their elite status, their professional community, and their operational significance as the only body that linked disparate sites and practices across the country. Indeed the reticence with which the Inspectorate was said to exercise its governing power was one of its hallmarks: it was characterised both by "a deliberate eschewing of authority" and also the "subtle way in which they use their power or influence" (Kogan 1970, 20). In this period (1940s to 1960s) HMI inspected schools infrequently, but provided "unbiased expert opinion" on performance. They visited schools, says Kogan, "...not to issue instruction, but to pass on knowledge acquired through the national network of inspectors, about new trends of thinking in education" (Kogan 1970, 20). From the 1960s, the discourse shifted, and the inspectorate became linked to the growth of local schools advisory services in the counties and the cities. By the 1970s, school inspection was no longer only the work of $\mathrm{HM}$ Inspectors, as local authorities, to varying degrees, had developed their own advisory services.

By 1975 there were nearly 1,700 LEA inspectors in England, including a significant number of advisers appointed to work with secondary head teachers, following comprehensive school reorganization, and the first substantial recruitment of advisers specifically for primary education (Smith 2000, 335). So, although an evaluative oversight remained the province of HMI, by the 1970s, it resembled a national advisory service. As education became re-politicised in the second half of the 1970s, Prime Minister Callaghan demanded to know: "What is the role of the Inspectorate in respect of national standards and their maintenance?" (Maclure 1988, 157).

By the mid 1980s, the inspectorate's claims to a combination of professionalism and independence were challenged in the context of the Thatcherite critique of public services and $\mathrm{HMI}$ were attacked for their "progressive 
and often radical" approach (Bolton 1998, 335). There was growing government dissatisfaction with $\mathrm{HMI}$ reports that seemed implicitly critical of Government actions or policies (or were presented as such by the opposition parties and/or the media), alongside hostility towards LEA inspectorates and $\mathrm{HMI}$ from influential right-wing think tanks, who regarded inspection procedures as inadequate, and who also suspected HMI and LEA inspectors of subscribing to "trendy" educational theories. The problem came to be identified as a knowledge and intelligence deficit in policy making. Instead of direct attacks on the "independent" HMI, the challenge was constructed as a problem of lack of evidence: on what evidence were HMI making judgements?

By 1989, against a backdrop of accelerated change in the management and organisation of public sector services including education, with the encouragement of marketisation, increased competition, and the growth of quangos and agencies, Her Majesty's Inspectorate was publicly and heavily involved in policy making: its remit was much more tightly linked to reporting and advising on policy and its implementation across the whole of the education service (Bolton 1998). In becoming more politicised, the inspectorate also became more vulnerable to challenges about the basis of its evidence and judgement. Its replacement by Ofsted in 1992 reflected the changing approach to governing public services and the increased suspicion of policy makers that HMI had "gone native".

There is a critical point here in understanding inspection: it continues over time but may do so in a radically transformed condition. In 1992 in England it took a new organisational form and a new organisational location within the changing architecture of public service governance, and its personnel were changed. At the same time, the object of inspection shifted towards transformation of the system of schooling, and this brought with it new systematised practices, techniques and technologies of inspection. HM Inspectors came under pressure to demonstrate their capacity to deliver output-based criteria of judgement, in line with changes in public sector accountability more generally. A new governing architecture, dependent on forms of scrutiny, evaluation, audit and inspection took on increasingly important roles as a means of managing more dispersed or fragmented systems of provision. The new arrangements for governing schooling, as in many public services, were articulated around the principles of "governing at a distance" rather than through the systems of integral government department bureaucracies.
Ofsted is a non-ministerial government agency that commissions private sector providers to carry out inspections of state schools. It was created because $\mathrm{HMI}-$ who included distinguished educationalists - were seen by reforming governments as elitist, more focused on influencing government than on schools, and vulnerable to producer capture. Ofsted came into existence with the promise that every school (primary and secondary) in England would be inspected within four years, and would then receive repeated inspections. Indeed, the centrality of inspection to the role and practice of Ofsted was embodied in its first corporate mission statement: "Improvement through Inspection". The scope of inspection also demanded a change in staffing: the core HM Inspectorate shrank from around 515 to 300 and inspections were to be staffed largely through a larger body of sub-contracted inspectors, as the inspection process was contractualised and put out for tender.

Initially, the culture and style of HMI seemed to dominate, both within the new organisation and in its relations to government. However, the appointment of Chris Woodhead as Her Majesty's Chief Inspector ( $\mathrm{HMCl})$ in 1994 (he served until 2000) is viewed as changing the style of the organisation in a number of ways. Smith (2000), for example, describes him as leading a transformation of Ofsted into a "campaigning organisation", which adopted more or less explicit stances on teaching methods, the quality of teachers, the curriculum, and pupil performance. He-and the organisation-also propounded an almost messianic belief in the transformative power of inspection (despite limited or even contradictory evidence about its impact on improving attainment).

However, by 2010 , it was evident that problems with system steering through inspection remained: more regulation did not necessarily solve the problem of accuracy and reliability of knowledge about school and national progress, and the increased cost of inspection did not necessarily imply more effective controls (Ozga 2009). Evidence grew that schools were "gaming the system", for example by excluding "difficult" children during inspection periods, or by sharing information about inspectors and inspection. As one of our informants put it, reflecting on the need to change inspection frameworks:

...it looked as though we were increasingly getting less of a return on our investment. And I think there is something quite interesting there for inspection systemsthat if you keep them rigidly the way they are then after 
a while you get fewer bangs for your buck - people start to game the system, inspectors may fall back on complacent behaviours and attitudes-your system can get locked when education generally is moving on (senior HMI 03)

\section{The History of Inspection in Scotland}

Like its counterpart in England, Her Majesty's Inspectorate in Scotland had long been a powerful presence with influence in policy formation within and outside the central education department there. Indeed, its history suggests that it was even more powerful than its English equivalent, in part because of the small scale of the country, while the absence of strong local government gave it extraordinary reach into the schooling system, and also because a tradition of centralised authority in Scotland provided a setting in which the inspectorate could exert considerable influence. Some commentators have suggested that that tradition expressed dependence on central direction, and acceptance of a somewhat authoritarian relationship between the inspectorate, as a policy elite, and the teaching profession (Humes 1986). The quotation below, from a former Senior Chief Inspector, conveys their historical role and their view of themselves:

Inspectors promote [Department] policy as a central aim of their day-to-day business. But they are also instrumental in the compilation of these [policy] documents, for their unique knowledge of schools, and their relationship with people in all parts of the educational system which enable them to sound opinions freely, and contribute most of the evidence on which the recommendations are based (McPherson \& Raab 1988, 135-6).

McPherson and Raab interpret the history of the inspectorate as one of strong positioning from 1945 onwards, as it had the monopoly of inspection functions - there were no local inspectors. It should also be remembered that, in these pre-devolution days, the then Scottish Office Education Department looked to the inspectorate to provide system leadership, as the central department defined itself primarily as an administrative unit. This was because Scottish education was recognised historically as one of the defining institutions of Scottish identity, and-along with the Law and the Church-remained distinctive following the Union of Parliaments of Scotland and England in 1707. The UK government based in Whitehall took little interest in education in Scotland, regarding it as a separate system. Within this framework of separate development the inspectorate enjoyed the predominant position in edu- cation in Scotland until the 1960s when "the Inspectorate's wings were clipped" (McPherson \& Raab 1988, 148). McPherson and Raab associate this change with the beginnings of attempts by the Scottish Education Department to more actively manage the system as the demands on it became more complex: for example in planning for new, larger-scale comprehensive schools. The role of the inspectorate in these processes is viewed more or less critically by commentators: they are seen to be agents of more managerial tendencies in the Department (Humes 1986, 74) trading their political independence for power, and as using their position and resources to "bolster their own position" (McPherson \& Raab 1988, 151).

It is probable that the inspectorate in this period both increased its power and became more overtly political, as professional and policy divisions about key directions increased throughout the 1960s and 70s, and these threatened their traditional claims to objective, expertisebased authority. However the Inspectorate continued to be a major force in Scottish education, expanding its remit and activities: indeed, the fragmentation of a previously very standardised school system offered Her Majesty's Inspectorate of Education the chance to claim a unifying authority and knowledge that no other group could match.

Throughout the 1980s and 1990s there were considerable tensions between the Conservative UK governments, the subsequent UK New Labour administrations and those responsible for education in Scotland. The Inspectorate becomes a presence at an "increasing number of points of articulation" of the system (McPherson \& Raab 1988, 494). The political context changes very substantially with the (re) creation of the Scottish parliament in 1999, and senior HMI were influential in drafting the first education act of the new Scottish Parliament in 2000, which placed legal obligations on schools and education authorities to manage improvement. The Standards in Scotland's Schools Act set out statutory requirements for school improvement within a framework encompassing a set of five National Priorities (Scottish Parliament, 2000).

However the Inspectorate became implicated in a crisis about examination marks in 2000 , and the existence of a Scottish government and Parliament changed the political landscape and provided an opportunity for the expression of some resentment of the inspectorate's dominant role in Scottish education. The establishment of the Parliament to some extent undermined the inspectorate's claim to be the champion of Scottish interests 
against the UK political leadership, and, as "the exam crisis provided the opportunity to drive the attack home" the Inspectorate lost its policy-making role (Raffe, Howieson \& Tinklin 2002) and ceased to be an independent body, becoming instead an executive agency, directly accountable to Ministers and not to the Crown. As one of our informants put it, reflecting on this period:

We no longer have a formal role in leading policy or leading development.... when we became an agency we no longer have that title. Formally we give professional advice....there could be recommendations and so on but when I joined HMI in 1992 I wrote my first speech for [the then Minister] within a fortnight. This no longer happens. We are now notably at second hand (HMIE 03)

However the Scottish Inspectorate seems to have recovered its position in recent years, as the policy context in which they are embedded has changed further. The election of the Scottish National Party (SNP) government in Scotland in 2007 (at first as a minority government, and then from 2011 with a majority), sees both a recovery and, indeed a movement beyond the inspectorate's traditional role to promote and self identify as "teachers" of good practice within Scotland and indeed, within Europe.

\section{THE CONTEMPORARY CONTEXT: OFSTED IN ENGLAND}

I think in England we have too much data and a lot of the inspectors don't really understand it. ...I mean data-you can make it say anything you want it to and it's difficult to refute in an inspection, or to say something different from what the data appear to be saying....say you are in the bottom left hand quadrant. It's very difficult to say in a report... well yes you are there but in actual fact the school is much better than that and there are reasons why, but Ofsted will say, but the data says this (Contract inspector $14^{2}$ ).

Ofsted is currently located in a governing project for education that embraces diversity of school provision and a process of centralisation/decentralisation to a degree that makes it difficult to "see" a system of education in England. However, as the system and its agents-including inspectors-become more opaque, so demands for data, the merging of system data, and the vision of education seem in themselves to constitute the new landscape of English education. Inspectors, who once acted as the source of knowledge for system man- agement, are now challenged, even superseded, by the growing power of system data. This threatens their position as policy actors in England and across Europe, as well as threatening their constitution as a profession. If system knowledge is no longer theirs alone, then their work can be disaggregated and different elements of it contracted out, including to commercial providers. Indeed, their opinions may have to compete with those of metadata analysts, think tanks and commercial organisations. As data move between school and centre and back again, responses to them are shaped by external influences, especially, in the twenty-first century, by England's global positioning, which influences education policy by reference to the threat of being overtaken by Finland, Singapore and other competitors (Department for Education 2010).

That global positioning also affects Ofsted's representation within Europe. In marked contrast to Scotland, the representation of the English inspection system inside the Standing International Conference on Inspection (SICl) and thus to Europe has not been strongly pursued (Grek et al. 2013). Although a founding member of SICl, and with the Netherlands, an important driver of it in the early years, the developing versions of the English model have not been exportable in Europe. However, the Ofsted model has influenced systems in other parts of the world, including in China. In the governing of the system, it is data and constant comparison that are used to shape, reward, exhort and punish schools and to present their performance nationally and internationally.

The work of the inspectorate in England, as specified by inspection frameworks and handbooks, changed constantly from 1992 onwards, and continues to change. Substantial changes took place in 2005 and again in 2009 when the number of private contractors approved by Ofsted to carry out inspections was reduced to just three, with the aim of reducing costs and improving inspection efficiency (Ofsted 2009). Further change in 2010 with the arrival of the UK coalition government of Conservatives and Liberal Democrats produced proposals for schools and teaching in England that currently frame the role of Ofsted, and resulted in a new inspection framework introduced in 2012 (Ofsted 2012).

The introduction of a new inspection framework by the UK coalition government marks a very significant change in Ofsted's definitions of success and failure. In the new framework four key judgements determine how well the school is performing: achievement of pupils, quality of teaching, behaviour and safety of pupils and overall effec- 
tiveness. There is a much tighter specification of the relationship between the grades for each category and the overarching judgement. The new framework gave much higher priority than previously to the observation of teaching and to its evaluation over time: that is, inspectors are now required to make a judgment of the extent to which pupil learning has been effective over a specific time period rather than in a single observed lesson. In addition, the new framework changed the grades to be awarded by inspection from the 4 categories of Special Measures; Satisfactory, Good and Outstanding to Special Measures, Requires Improvement, Good and Outstanding. The removal of "satisfactory" as a grade reflects political frustration with the lack of impact of inspection on the performance of many schools.

The new Framework and Inspection Schedule bring considerable challenges to the role of the inspector, challenges that were becoming apparent in our research as the training process for the new framework unfolded. Inspectors are being asked to use "professional judgement" while greatly increasing the number of failing schools (an inevitable consequence of the abolition of the "satisfactory" grade): they are also asked to "take account of context" but value-added data are not permitted: they must assess teaching but have no clear criteria for doing so. There is considerable disquiet among the inspectorate:

In the previous framework there was a very clear formula, so if you got this and this it would have to be that. This government wants to move away from that formulaic approach and build in the professional judgement. That said, what we are seeing is that when $\mathrm{HMl}$ read the report, 'cos at the moment they are reading every report, they are questioning the judgements that we made... questioning the professional judgements (Contract inspector 10).

These extracts illustrate the ways in which the power of data both creates problems and offers solutions at several levels. Data threaten the knowledge-based power of the inspectorate and yet data also enable inspectors to make school judgments quickly; data enable private contractors to manage their performance and increase the flexibility of the inspectors that they employ; data bypass the hierarchical structures of governing education and yet allow coordination of an increasingly complex landscape of public-private education provider hybrids and multiple school types (Ozga 2013). In this complex and contradictory landscape, the trajectory of the inspectorate is shaped by the demands on them: their role is redefined as the servants of data and as the "shock troops" of a data driven system. Is this a sufficient basis for the future of Ofsted? A senior inspector, considering the implications of the increased role and accessibility of data for the future of inspection, suggested that it might not be:

I do ask myself whether what you might describe as old fashioned inspection is going to quite have the same power.... because we're putting more information out all the time about the performance of schools - and that's another thing this government has done-to make all this data available-and-if that becomes more regularly used and you get a kind of "trip adviser" view of how schools are doing-you might think, well-pretty imperfect that. The problem is however imperfect it is it could leave inspection standing [still] (senior HMI 03).

\section{THE CONTEMPORARY CONTEXT: EDUCATION SCOTLAND}

There is evidence of divergence in education policy between Scotland and England from the late 1970s onwards, when the Conservative-controlled UK administrations re-made education in line with market principles. However whereas England introduced a National Curriculum with National Testing and a strong focus on hard performance indicators, these approaches were successfully resisted in Scotland. Scotland did not create a data-driven system and the Scottish Inspectorate continued to be recruited from a professional base of teachers even in its period of diminished autonomy: it did not recruit from, or make use of, commercial agencies. These factors established conditions that enabled the rapid recovery of the Scottish inspectorate's role and position, albeit in a rather different mode.

The Scottish National Party (SNP) government in Scotland brought about considerable change in the style of government (Arnot \& Ozga 2010). Decentralisation is a key principle of the SNP's redesign of governance in Scotland; it is promoted as a way of building an independent Scottish state. The SNP government argue that decentralisation demonstrates maturity in the political process, developing from political devolution, and enables the growth of accountability and hence trust between government and its partners, local authorities and other stakeholders. The SNP Government, a majority government since the May 2011 election, has attempted to "craft a narrative" of joint or collective learning that connects to growing national capacity and independence through education. Expert judgment, evidence, the 
building of trust and constant learning from self-evaluation are referenced as elements in building this capacity, not only in relation to education/learning policy and institutions, but more broadly as a key support for governing. In this context the Inspectorate are once again significant policy actors: they carry the self-evaluation agenda into a receptive European space, and they model and "teach" self-evaluation within the national space.

The Scottish government is actively pro-European, and seeks to discursively re-position "smarter Scotland" alongside selected small, social democratic states in Europe, especially Norway and Sweden, and to use Europe as a platform for the projection of a distinctive Scottish identity (Grek \& Ozga 2010). The Scottish inspectorate takes advantage of this external platform to explain the "distinctiveness of Scotland" to Europe, and to promote Scotland's approach to self-evaluation as "in line with evolving European-wide models" (HMle3). They are actively involved in developing inspection regimes as inspection grows in significance within Europe, and this is reflected in their very active participation in the Standing International Conference of Inspectorates $(\mathrm{SICl})$. Scotland has provided two Presidents of $\mathrm{SICl}$ and the growth of international comparison especially through PISA has provided it with a stronger role in interpreting and translating international data across and within systems.

An indicator of Scottish influence is the $\mathrm{SICI}$ Inspection Academy, and there is evidence of more formal, contractual "consultancy" work, through which Scotland has been "teaching" self-evaluation to Europe:

...individual countries within that group being aware that Scotland was doing something they found quite interesting and productive and constructive. And they came to us and were interested. And therefore we've had this dialogue... (HMle 05).

The key policy technology that the Scottish inspectorate has promoted in Europe and within Scotland is school self-evaluation (SSE) as set out in the key text "How Good is our School" (HGIOS):

Scotland is certainly one of the early pioneers of selfevaluation -the thing that attracted so much attention to the system here was just the way HGIOS was produced as very school-focused, schools found it easy to use, accessible-an easy way of capturing data-so HGIOS has been very much discussed and the momentum often translated-whereas other inspectorates - as in England-have tended to produce things that were written as inspection guidelines (HMle 01) (emphasis in original).

Within Scotland, as well as externally, SSE has provided the inspectorate with a means of recovering its status and role, and offered a new way in which they can shape the system. School self-evaluation seeks to create a school evaluation framework that brings about constant comparison and improvement, broadly focusing on answering two key questions about educational practice: "How good are we now?" in order to identify strengths and development needs in key aspects of teachers' work and the impact it has on learners; and "How good can we be?" in order to set priorities for improvement. HGIOS positions the inspectors as guides and enablers of quality assurance processes that are built and maintained by the school. This enables a shift to the apparent "light touch" of new inspection practices, while co-opting schools further into the new networks of knowledge production. Furthermore, this knowledge becomes productive for the constant improvement not only of the individual school, but for the governing of the system as a whole.

The growth of self-evaluation has been supported by development of inspection practices that stress schools' responsibility for their continuous quality monitoring, evaluating and reporting processes, and recast the Scottish Inspectorate as "teachers" of the system, modelling through their own practice and expert judgment the qualities that good teachers should develop and display. This development is promoted by the Scottish government as a shift from central control to deregulation, and is connected to the promotion of the government as a "learning government", working in concert with its partners and thus creating more confident individuals that have the capacity for political independence. The current positioning of the inspectorate in Scotland seems to be quite closely aligned with this governing "narrative" of the SNP government which is, in turn, built around the idea of collective learning that provides a resource for strengthened national identity, growing national capacity and hence political independence. The inspectorate thus has a very important role to play as "translators" of this narrative into practice through their use of judgement, evidence, and the building of trust through self evaluation, which they propagate as a key resource for better public sector management and accountability, while they model and "teach" self-evaluation within the national policy space.

HGIOS positions the inspectorate as guides and enablers of quality assurance processes that are built and maintained by the school, using HMIE guidance. Self- 
evaluation, then, builds towards system "greatness" through inspection:

[l]nspection is part of that self-evaluation.... [W] hat the inspection is providing is the mirror of a national perspective against which a school can reflect its own performance (HMle 02).

In 2011 a new body-Education Scotland-was created, combining The Scottish Inspectorate (HMIE) with Learning and Teaching Scotland (the former curriculum development agency) and thus heavily underlining the alignment of inspection with improvement. The role of the inspectorate in this new alignment is to "gather intelligence, advise and intervene" to support a "learning system through which the professionals at the front line create the forward planning and the forward movement" in a system described by a senior policy actor as:

...much more based on schools being the primary agent of self-evaluation, with what we tend to describe as a kind of peer coaching that we bring in with inspection for schools, rather than an external evaluation of schools (HMle 07).

At the same time, inspection has continued to emphasise building good relations with local schools and local authorities in the drive for improvement. The development of a partnership view of inspection places a premium on support and developmental practices, reinforced by psychological training that seeks to develop appropriate skills:

We're training our people quite actively in the social skills of inspection... we've got some occupational psychologists working with us to develop this frameworkworking on relationships with people-we must be able to win the support and constructive interest that will enable initiative (HMle 03).

In fact:

\begin{abstract}
...how you inspect is almost more important than being right, in terms of making the judgments. I remember one time, 20 years ago, the absolute-getting the judgment right was what mattered, nothing else-whereas now it's the social skills of being able to manage inspection to the point where you leave the school actually able to improve because they accept and are with you on the agenda-that's the real skill of inspection (HMle 03).
\end{abstract}

Self evaluation thus represents and encapsulates a new governing idea and has laid the foundations for the next stage in the trajectory of development of an intelligence-led, proportionate inspection system that operates in a "performance-coaching" way. This view of their role is promoted by the inspectorate as a progressive programme of reform based on peer-led learning and the creation of professional learning communities with the aim of decentralising learning and promoting innovation. The motto of the new Scottish inspection system is "to live the talk" of being self-evaluative, hence to constantly be looking at international benchmarking and the best systems elsewhere. According to this new agenda, the role of the inspectorate is to build from the bottom, invest in capacity for front line professionals and steer from the top in a light way:

This is no micro-management, quite the opposite of that... Education Scotland has the role of choreographing and managing careful balance of pressure and support from the sides (HMle 02).

\section{CONCLUSION}

Our intention in this paper is to illustrate the trajectories of the two inspection systems, in England and Scotland, in their distinctive political and policy contexts. Through most of the twentieth century challenges to their role in their education systems were contained within their national borders, but this is no longer the case. The influence of increasingly complex comparative data and the consequent pressures for shared policy solutions mean that challenges to historically-embedded positions often arrive from elsewhere at a speed and on a scale that demand transnational and international referencing, exchange and action. The positioning of the two inspectorates in Europe and the global arena, although different, supports their continuing existence. From the Scottish inspectorate's European and SICl-based influence to global marketing of Ofsted's model to developing countries, it is clear that international influence helps to maintain and shape the national influence of inspectorates.

European education systems have moved towards governing through performance management and apparently objective, data based knowledge that increases transparency and thus away from earlier forms of governing through judgment and highly contextualised knowledge, but significant differences in the degree of this shift remain. The ways in which national systems deal with the rise of data, comparison and calculability and their use to control and shape behaviour (Lawn 2006) is crucial to our understanding of system governing, and to the place of inspection regimes within the governing of education. It is often argued that the key to new governing lies in inculcating norms and values through which 
external regulatory mechanisms transform the conduct of organisations and individuals in their capacity as "selfactualising" agents, so as to achieve political objectives through "action at a distance" (Miller \& Rose 2008, 1). In the case of Scotland, the power of data has been domesticated and integrated into a national narrative of improvement, in which the national endeavour is harnessed and mentored by the inspectors, and data themselves play a secondary role. In England, the power of data has been unleashed to define and judge performance and also to govern an increasingly heterogeneous agglomeration of schools and drive choice in an education marketplace. Ofsted's trajectory of development in this "systemless system" (Lawn 2013) is harder to discern: the inspector- ate is vulnerable to political pressure and faces an uncertain future. Both inspection regimes are heavily implicated in seeking solutions to governing problems: what our research demonstrates is that the place of inspection in governing is not static, and changes according to the definition of the problems it is asked to address. These vary, but they are always governing problems.

Jenny Ozga
jennifer.ozga@education.ox.ac.uk
University of Oxford, Department of Education
Martin Lawn
m.lawn@btopenworld.com
of Edinburgh, Centre for Educational Sociology

University of Edinburgh, Centre for Educational Sociology

\section{NOTES}

1 "Governing by Inspection: Governance and School Inspection In England, Scotland and Sweden ESRC RES 06223 2241A". The authors acknowledge the support of their Research Council. The views expressed in this paper are their own and not necessarily those of the Council. For further information on the project see $<$ www.education.ox.ac.uk/governing-by-inspection/>
2 We protect the anonymity of our informants by referring only to their roles: contract inspectors work for one of the providers (SERCO, TRIBAL or CfBT) who are contracted to provide the bulk of inspection services in England.

\section{REFERENCES}

ALLEN G. C. (1960). "HM Inspector of Schools: A personal impression". International Review of Education 6, no. 2: 235-9.

ARNOTT M. \& OZGA J. (2010). "Education and nationalism: The discourse of education policy in Scotland". Discourse: Studies in the Cultural Politics of Education 31, no. 3: 335-350.

BOLTON E. (1988). "The Thatcher Years". Oxford Review of Education 24, no. 1: 45-55.

CLARKE J. (2009). "Governance puzzles”. In L. Budd \& L. Harris (eds), eGovernance: Managing or Governing, 29-52. London: Routledge.

DEPARTMENT FOR EDUCATION (DfE) (2010). The White Paper: the importance of teaching. London: DfE

FAIRCLOUGH N. (2001). "The discourse of New Labour: critical discourse analysis?”. In M. Wetherell, S. Taylor \& S. Yates (eds), Discourse as data: A guide for analysis, 55-70. Buckingham: Open University Press.

GREK S. (2009). 'Governing by numbers: the PISA \effect' in Europe". Journal of Education Policy 24(1): 23-37.

GREK S. (2013). "Travelling the Caledonian Way". Paper presented to the Governing by Inspection: school inspection and education governance in Scotland, Sweden and England Policy Workshop. Edinburgh University School of Social and Political Science, December 16th 2013.

GREK S., LAWN M., OZGA J. \& SEGERHOLM C. (2013). "Gover- ning by Inspection? European Inspectorates and the creation of a European Education Policy Space". Comparative Education 49, no. 4: 486-502

GREK S. \& LINDGREN J. (eds) (2014). Governing by Inspection: School Inspection and Education Governance in England, Scotland and Sweden. London: Routledge (in Press).

GREK S. \& OZGA J. (2010). "Governing education through data: Scotland, England and the European education policy space". British Education Research Journal 36(6): 937-952.

HUMES W. (1986) The Leadership Class in Scottish Education. Edinburgh: Edinburgh University Press.

KOGAN M. (1971). The Government of Education. London: MacMillan Education.

LAWN M. (2006). "Soft governance and the learning spaces of Europe". Comparative European Politics 4(2-3): 272-288.

LAWN M. (2013). "A Systemless System: Designing the disarticulation of English state education". European Educational Research Journal 12(2): 231-241.

LASCOUMBES P. \& LE GALÈS P (2007). "Understanding Public Policy through its instruments-from the nature of instruments to the sociology of public policy instrumentation". Governance 20(1): 1-21.

MACLURE S (1998). "Through the Revolution and out the other side". Oxford Review of Education 24 (1): 2-24. 
MCPHERSON A. \& RAAB C. (1988). Governing Education: A Policy Sociology. Edinburgh: Edinburgh University Press.

MILLER P. \& ROSE N. (2008). Governing the Present: Administering Economic, Social and Personal Life. Cambridge: Polity Press.

OFFICE FOR STANDARDS IN EDUCATION (Ofsted) (2009). The framework for school inspection in England under section 5 of the Education Act 2005. London: Ofsted.

OFSTED (2012). The Framework for School Inspection. London: Ofsted.

OZGA J. (2009). "Governing Education through Data in England: From Regulation to Self-Evaluation". Journal of Education Policy 24(2): 149-163.

OZGA J. (2013). "Accountability as a policy technology: Accounting for education performance in Europe". International Review of Administrative Sciences 79, no. 2: 292-309.

OZGA J. \& LAWN M. (eds) (2014). "Frameworks of Regulation: Evidence, Knowledge and Judgement in Inspection". Special Issue of Sisyphus-Journal of Education 2, no. 1: 7-127.
OZGA J., DAHLER-LARSEN P., SEGERHOLM C. \& SIMOLA H. (eds) (2011). Fabricating Quality in Education: Data and Governance in Europe. London: Routledge.

RAFFE D., HOWIESON C. \& TINKLIN T. (2002). "The Scottish Educational Crisis of 2000: An Analysis of the Policy Process of Unification". Journal of Education Policy 17, no. 2: 167-185.

SCOTTISH PARLIAMENT (2000). Standards in Scotland's schools etc. Act. <http://www.opsi.gov.uk/legislation/scotland/ acts2000/20000006.htm> (consulted November 14, 2012).

SMITH G. (2000). "Research and Inspection: HMI and OFSTED, 1981-1996-a commentary". Oxford Review of Education 26(3): 333-352.

TERSMETTE E (2001). Benchmarking of Quality in Education: a European perspective. Speech to SICl, Utrecht, 19 October 2001. 